\title{
Growth of CZTS Thin Films by Cosputtering of Metal Targets and Sulfurization in $\mathrm{H}_{2} \mathrm{~S}$
}

\author{
N. Muhunthan, Om Pal Singh, Son Singh, and V. N. Singh \\ CSIR-National Physical Laboratory, Dr. K. S. Krishnan Marg, New Delhi 110012, India \\ Correspondence should be addressed to V. N. Singh; vidyanands@yahoo.com
}

Received 24 May 2013; Accepted 12 July 2013

Academic Editor: Raghu N. Bhattacharya

Copyright (c) 2013 N. Muhunthan et al. This is an open access article distributed under the Creative Commons Attribution License, which permits unrestricted use, distribution, and reproduction in any medium, provided the original work is properly cited.

Copper zinc tin sulfide (CZTS) is an emerging thin film photovoltaic material. Chemical composition and phase purity are important factors which decide the quality of the film for photovoltaic applications. In the present work, we report the results of the morphological, structural, optical, and electrical characterizations of $\mathrm{Cu}_{2} \mathrm{ZnSnS}_{4}$ thin films, synthesized by sulfurizing magnetron cosputtered $\mathrm{Cu}_{2} \mathrm{ZnSn}$ thin films in ambient $\mathrm{H}_{2} \mathrm{~S}$. To the best of our knowledge, this is the first report on CZT deposition by cosputtering from $\mathrm{Cu}, \mathrm{Zn}$, and $\mathrm{Sn}$ targets and sulfurizing it in ambient $\mathrm{H}_{2} \mathrm{~S}$ for making CZTS thin films. GIXRD and Raman study results showed that the film was kesterite CZTS. Optical absorbance studies revealed a band gap value of $\sim 1.5 \mathrm{eV}$ for CZTS thin film. Results of the Hall effect measurements are also reported.

\section{Introduction}

Copper zinc tin sulfide (CZTS) is an emerging thin film solar photovoltaic absorber material and is composed of earth abundant, nontoxic, and cheaper materials. It is a semiconductor with a direct band gap of about $1.5 \mathrm{eV}$ and an absorption coefficient of $\sim 10^{4} \mathrm{~cm}^{-1}[1]$. Therefore, a thickness of $1-2 \mu \mathrm{m}$ is sufficient for absorbing the solar radiation. It is a good substitute for copper indium gallium selenide (CIGS) solar photovoltaic absorber, which is composed of rare, costly and relatively toxic materials. A record efficiency of $20.3 \%$ has been recorded for CIGS solar cell [2]. There are many issues which need to be answered in order to improve the stability and other characteristics of the solar cell. As both CZTS and CIGS solar cells have similar physics working for them, it is economical to carry out detailed research on CZTS [3]. In order to commercialize CZTS thin film solar cell, its efficiency needs to be enhanced. The highest reported efficiency of CZTS solar cell by Todorov et al. is 11.1\% [4]. Different methods for synthesizing CZTS absorber materials have been reported in the literature [5-18]. The methods include thermal evaporation [5], sputtering from metal targets (layer by layer) [6], sputtering from sulfide or composite targets [7], pulsed-laser depositions [8], chemical methods (sol-gel)
[9], electrodeposition [10], and nanocrystals synthesis [11]. Among the physical vapor deposition techniques, sputtering is widely used in industry. Although, stoichiometric films can be deposited using PLD, small substrate size is its limitation. Composition of the film plays an important role in determining the efficiency of the solar cell. As different elements have different sputter rates, sputtering using CZTS alloy targets may not permit the necessary control over the composition of the CZTS film. CuS, ZnS, SnS, and so forth are some of the common secondary phases that can nucleate while synthesizing CZTS thin films. The presence of secondary phases may act as recombination centers in the solar cell and can degrade the quality of the cell. In this study, $\mathrm{Cu}_{2} \mathrm{ZnSn}$ thin films have been synthesized by cosputtering $\mathrm{Cu}, \mathrm{Zn}$ and $\mathrm{Sn}$ targets. This gave the freedom to control the amount of different metals individually by controlling the sputtering power. The $\mathrm{Cu}_{2} \mathrm{ZnSn}$ film has been sulfurized in ambient $\mathrm{H}_{2} \mathrm{~S}$ in order to obtain CZTS thin films. A summary of sputtering methods used for depositing the CZTS films, sputtering target used and the sulfurization conditions used in the literature is presented in Table $1[7,8,12-18]$. From the table, it is clear that this is the first report on the synthesis of $\mathrm{Cu}_{2} \mathrm{ZnSn}$ thin films by cosputtering from $\mathrm{Cu}, \mathrm{Zn}$, and $\mathrm{Sn}$ metal targets and carrying out sulfurization in ambient $\mathrm{H}_{2} \mathrm{~S}$. 
TABLE 1: Different sputtering methods used for depositing CZTS thin films.

\begin{tabular}{|c|c|c|c|}
\hline Sputtering methods & Targets & Sulfurization conditions & References \\
\hline RF cosputtering & $\mathrm{Cu}, \mathrm{ZnS}, \mathrm{SnS}$ & $\mathrm{H}_{2} \mathrm{~S}(20 \%)+\mathrm{N}_{2}$ at $580^{\circ} \mathrm{C}$ for $3 \mathrm{~h}$ & [7] \\
\hline RF sputtering & $\begin{array}{l}\text { CZTS (sintered with } \\
\mathrm{Cu}_{2} \mathrm{~S}: \mathrm{ZnS}: \mathrm{SnS}_{2}=1: 1: 1 \text { ) }\end{array}$ & Annealed at $400^{\circ} \mathrm{C} / 30 \mathrm{~min}$ during deposition & {$[8]$} \\
\hline Dc reactive sputtering & $\begin{array}{l}\mathrm{Cu}: \mathrm{Zn}: \mathrm{Sn}=2: 1: 1 \\
\left(\mathrm{H}_{2} \mathrm{~S}+\mathrm{Ar}\right) \text { at } 500^{\circ} \mathrm{C} \text { for } 60 \mathrm{~min}\end{array}$ & - & {$[12]$} \\
\hline Sputtering (layer by layer) & $\mathrm{Cu}, \mathrm{Zn}, \mathrm{Sn}$ & $\mathrm{S}$ at $250^{\circ} \mathrm{C}$, film at $570^{\circ} \mathrm{C}$ for $20 \mathrm{~min}$ & {$[13]$} \\
\hline RF cosputtering & $\mathrm{Cu}_{2} \mathrm{~S}, \mathrm{ZnS}, \mathrm{SnS}_{2}$ & $\mathrm{Ar}+\mathrm{S}_{2}(\mathrm{~g})$ at $250-400^{\circ} \mathrm{C}$ for $1 \mathrm{~h}$ & {$[14]$} \\
\hline RF cosputtering & CuSn $(60: 40), \mathrm{ZnS}$ & $\mathrm{S}(2 \mathrm{mg})$ at $520^{\circ} \mathrm{C}$ for $1 \mathrm{~h}$ & {$[15]$} \\
\hline Reactive sputtering $\left(50 \% \mathrm{H}_{2} \mathrm{~S} / \mathrm{Ar}\right)$ & $\mathrm{Cu}, \mathrm{Zn}, \mathrm{Sn}$ & $\begin{array}{l}\text { Annealed at } 40 \text { mtorr, } 550^{\circ} \mathrm{C} 10 \% \mathrm{H}_{2} \mathrm{~S} / \mathrm{Ar} \\
\text { mixture }\end{array}$ & {$[16]$} \\
\hline Simultaneous RF sputtering & $\mathrm{Cu}_{2} \mathrm{~S}, \mathrm{ZnS}, \mathrm{SnS}_{2}$ & $\begin{array}{l}\text { Annealed under sulfur vapor; sulfurization } \\
\text { temp was } 550,600 \text {, and } 650^{\circ} \mathrm{C}\end{array}$ & {$[17]$} \\
\hline Simultaneous (DC, RF) sputtering & $\mathrm{Cu}, \mathrm{ZnS}, \mathrm{SnS}$ & $\begin{array}{l}\mathrm{H}_{2} \mathrm{~S} \text { diluted with } 97 \% \mathrm{~N}_{2} \text {, annealed at } 500^{\circ} \mathrm{C} \\
\text { for } 10 \mathrm{~min}\end{array}$ & {$[18]$} \\
\hline
\end{tabular}

It should be noted that Yoo and Kim have also used three different metal targets for depositing metallic films, but they have made stacked/layered films [13]. In the present study, all the three targets have been sputtered simultaneously. It has been shown that the presence of any metal in excess may lead to the formation of secondary phase and stoichiometric film can be obtained only if the initial composition is controlled. The morphological analysis has been carried out using the SEM, and the chemical compositional analysis has been carried out using EDS attached with SEM. Structural analysis has been carried out using XRD, HRTEM, and Raman spectroscopic studies. The optical properties have been characterized using the UV-Vis spectrophotometer. Temperaturedependent electrical conductivity study has also been carried out in order to calculate the activation energy. The type of carrier, carrier concentration, and so forth have been evaluated using the Hall effect measurements.

\section{Experimental Details}

In order to deposit copper zinc tin $\left(\mathrm{Cu}_{2} \mathrm{ZnSn}\right)$ thin films, $\mathrm{Cu}, \mathrm{Zn}$, and $\mathrm{Sn}$ have been cosputtered from their metal targets. The depositions have been carried out in a magnetron sputtering system having arrangements for mounting three two-inch targets confocally. All three magnetron guns can be tilted $\pm 15^{\circ}$. An ion gun is mounted for final cleaning of the substrates. The system has substrate rotation as well as substrate heating facility. It is automated through a PLCPC-based automation system. In the present work, copper (99.999\%) has been deposited using DC power; Sn (99.999\%) and $\mathrm{Zn}(99.995 \%)$ have been deposited using RF power. The thickness of the individual metal can be controlled by controlling the power. In all the experiments, substrate temperature was $430 \mathrm{~K}$ and substrate rotation was $10 \mathrm{rpm}$. Prior to sputter deposition, a base pressure of $\sim 9.0 \times 10^{-7}$ mbar was achieved using a turbomolecular pump $(800 \mathrm{~L} / \mathrm{s})$. The depositions were carried out at a working pressure of $5.2 \times 10^{-3} \mathrm{mbar}$ with a argon flow rate of $80 \mathrm{sccm}$. Soda-lime glass (thickness $0.7 \mathrm{~mm}$ ) substrates were first cleaned in warm soap solution.
Then, they are ultrasonicated in acetone/alcohol/deionized water successively. Finally, they were dried in nitrogen flow. Sulfurization was carried out in a horizontal tube furnace fitted with quartz tube. At one end of the tube, gas supply arrangements were there, and on the other end, a rotary pump was fitted to pump down the system. CZT film was kept on an alumina holder at the centre of the furnace. The system was evacuated to $2 \times 10^{-2}$ mbar and flushed with nitrogen in order to remove any oxygen content. The sulfurization was carried out in the presence of $\mathrm{H}_{2} \mathrm{~S}$ gas (diluted with $85 \%$ Argon). The $\mathrm{H}_{2} \mathrm{~S}$ flow rate was $12.5 \mathrm{sccm}$ (controlled by mass flow controller). The furnace was heated to $400^{\circ} \mathrm{C}$ in $10 \mathrm{~min}$ and then to $550^{\circ} \mathrm{C}$ in next $10 \mathrm{~min}$ and was kept at $550^{\circ} \mathrm{C}$ for $25 \mathrm{~min}$. Then, it was allowed to cool down to room temperature. The outgoing gas was passed through aqueous $\mathrm{KOH}$.

Glancing incidence X-ray diffraction studies of the thin films were carried out using Philips X'pert pro X-ray diffractometer $\left(\mathrm{GI}-1^{\circ}\right)$. Morphological studies of the films were carried out using SEM (Zeiss EVO-50, scanning electron microscope). EDS studies were carried out using the EDAX attached with the SEM. X-ray florescence spectroscopic studies were carried out to determine the elemental composition (using a Rigaku Model 3070E Rh-target wavelengthdispersive XRF spectrometer). The Raman analysis of CZTS thin film was carried out using Jobin Yvon T64000, triple monochromator Raman spectrometer. Excitation (514.5 nm) was provided by argon ionized laser. Optical properties were studied using UV-Vis spectrophotometer (Shimadzu UV1800). Tecnai-G2 F-30, HRTEM was used for TEM studies. The electrical resistivity $(\rho)$, carrier concentration and mobility were measured in the Van der Pauw configuration on $3 \mathrm{~mm} \times 3 \mathrm{~mm}$ sample. Electrical measurements from $77 \mathrm{~K}$ to room temperature were carried out to estimate the activation energy.

Three samples having different $\mathrm{Cu}, \mathrm{Zn}, \mathrm{Sn}$, and $\mathrm{S}$ ratios were studied for their structural, morphological, and compositional properties. The details of the samples are presented in Table 2. The chemical compositions (determined using EDAX) are also presented in Table 2. 
TABLE 2: Chemical composition and the ratio of different elements in the samples.

\begin{tabular}{|c|c|c|c|c|c|c|c|}
\hline \multirow{2}{*}{ Sample } & \multicolumn{4}{|c|}{ Chemical composition } & \multicolumn{3}{|c|}{ Compositional ratio } \\
\hline & $\mathrm{Cu}($ at \%) & $\mathrm{Zn}($ at $\%)$ & Sn (at \%) & S (at \%) & $\mathrm{Cu} /(\mathrm{Zn}+\mathrm{Sn})$ & $\mathrm{Zn} / \mathrm{Sn}$ & S/metal \\
\hline 1 & 30.65 & 11.77 & 12.07 & 45.51 & 1.2856 & 0.9751 & 0.8352 \\
\hline 2 & 28.99 & 11.77 & 13.82 & 46.03 & 1.1328 & 0.8516 & 0.8433 \\
\hline 3 & 26.12 & 16.32 & 12.39 & 45.17 & 0.9097 & 1.3171 & 0.8258 \\
\hline
\end{tabular}

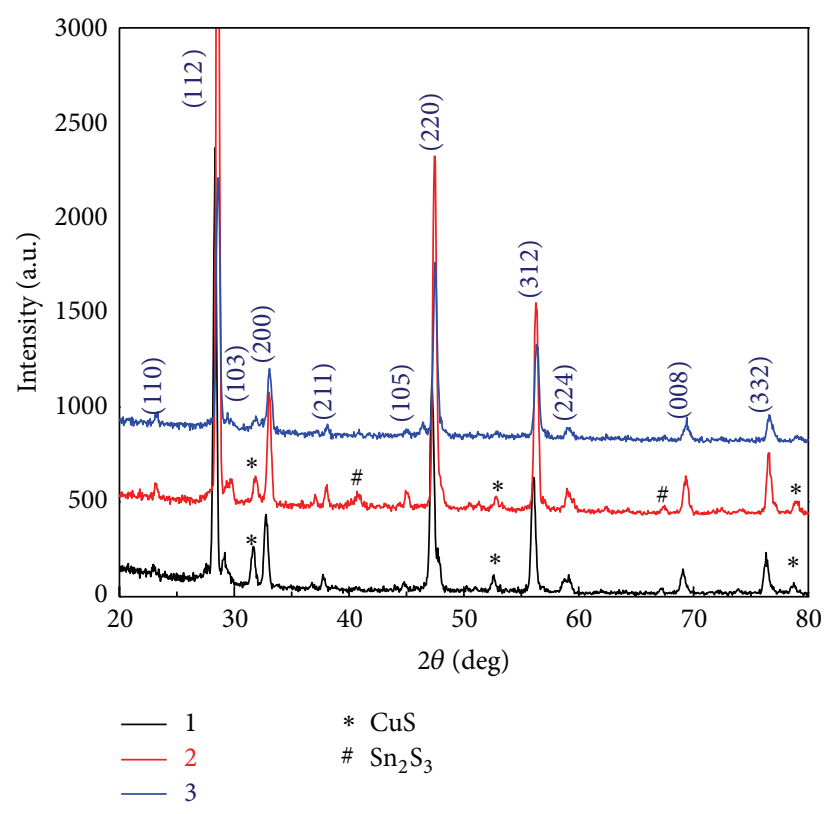

(a)

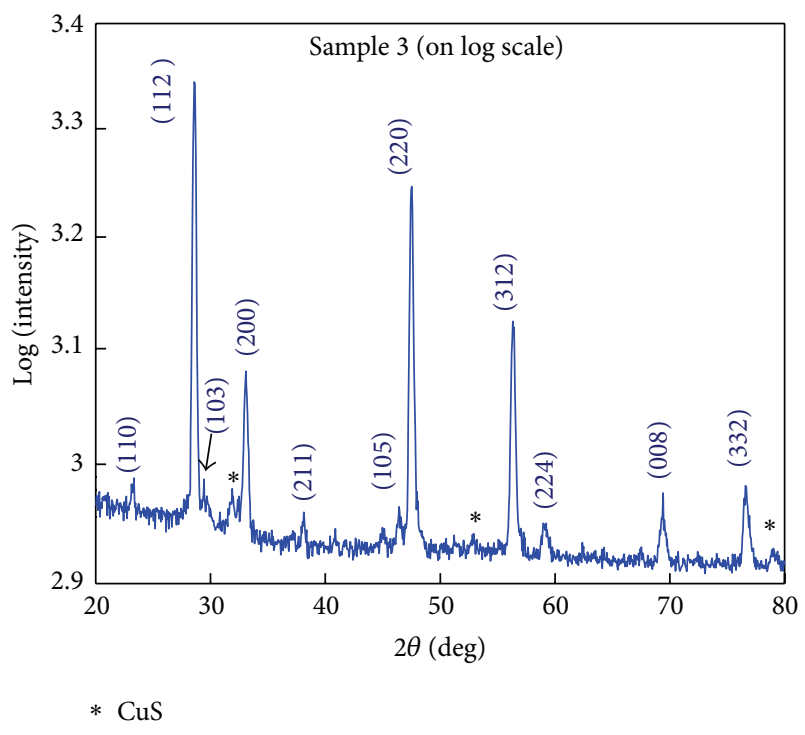

(b)

FIGURE 1: (a) GIXRD spectra of CZTS samples 1, 2, and 3 and (b) log scale plot of GIXRD of sample 3. Peaks corresponding to CZTS are shown, and peaks corresponding to $\mathrm{CuS}$ and $\mathrm{Sn}_{2} \mathrm{~S}_{3}$ are marked as $*$ and \#, respectively.

\section{Results and Discussions}

Figure 1 shows the glancing incidence X-ray diffraction patterns of CZTS samples 1-3. In the GIXRD [19] pattern of all three films (usually for thin film samples, XRD is carried out in glancing incidence mode in order to remove/minimize substrate effect), peaks corresponding to kesterite CZTS structure were observed and are indexed as (110), (112), (103), (200), (211), (105), (220), (312), (224), (008), and (332) planes in Figure 1 [20]. The diffraction pattern of sample 1 (Figure 1(a)) shows two types of crystal structures, one corresponding to CZTS and the other corresponding to $\mathrm{CuS}$ (at $2 \theta=31.7$ (103), 52.6 (108), and 78.7 (213); JCPDS no. 78-239) and are marked as $*$. The composition of the film (determined using EDS analysis) is presented in Table 2. The $\mathrm{Cu} /(\mathrm{Zn}+\mathrm{Sn})$ ratio of 1.28 and $\mathrm{Zn} / \mathrm{Sn}$ ratio of 0.97 showed that the film was copper rich and zinc poor. SEM micrograph of CZTS films is shown in Figures 2(a)-2(c). These hexagonal crystallites are assumed to be $\mathrm{CuS}$ as shown in the SEM micrograph of sample 1 (Figure 2(a)).

In the GIXRD pattern of sample 2 (Figure 1(a)), main peaks belong to kesterite CZTS. Apart from these, peaks of other binary sulfides such as $\mathrm{CuS}$ (marked as $*$ ) (at $2 \theta=$ 31.7 (103), 52.6 (108), and 78.7 (213); JCPDS no. 78-2391) and $\mathrm{Sn}_{2} \mathrm{~S}_{3}$ (marked as \#) (at $2 \theta=40.8$ (015) and 67.6 (325); JCPDF no. 75-2183) are also present. In the GIXRD spectrum of sample 2 , the peaks corresponding to $\mathrm{CuS}$ were less intense compared to peaks in GIXRD pattern of sample 1. Compositional analysis (by EDS) shows $\mathrm{Cu} /(\mathrm{Zn}+\mathrm{Sn})$ ratio of 1.13 and $\mathrm{Zn} / \mathrm{Sn}$ ratio of 0.85 . Thus, the film was copper, tin rich and zinc poor. In the SEM micrograph (Figure 2(b)), hexagonal shape is assumed to be of $\mathrm{CuS}$ crystallites, and cubical shape is assumed to be of $\mathrm{Sn}_{2} \mathrm{~S}_{3}$ crystallites which can be seen.

In the GIXRD pattern of sample 3 (Figure 1(a)), all the main intense peaks are due to CZTS kesterite phase. The GIXRD pattern plotted on log scale has been shown in Figure 1(b). It appears that minute quantity of $\mathrm{CuS}$ phase may also be present in the sample. The small values of full width at half maximum (FWHM) indicated the crystalline nature of the film. SEM micrograph (Figure 2(c)) of film reveals that the film consisted of columnar grains of about $100 \mathrm{~nm}$. EDS analysis showed $\mathrm{Cu} /(\mathrm{Zn}+\mathrm{Sn})$ ratio of 0.91 and $\mathrm{Zn} / \mathrm{Sn}$ ratio of 1.31. XRF spectroscopic studies were used to determine the atomic content of CZT and CZTS films (sample 3). For CZT film, the atomic percentages of $\mathrm{Cu}, \mathrm{Zn}$, and $\mathrm{Sn}$ were 52, 26, and 22\%, respectively, and for CZTS film atomic percentage of $\mathrm{Cu}, \mathrm{Zn}, \mathrm{Sn}$, and $\mathrm{S}$ were $21.3,16.8,12.4$, and 


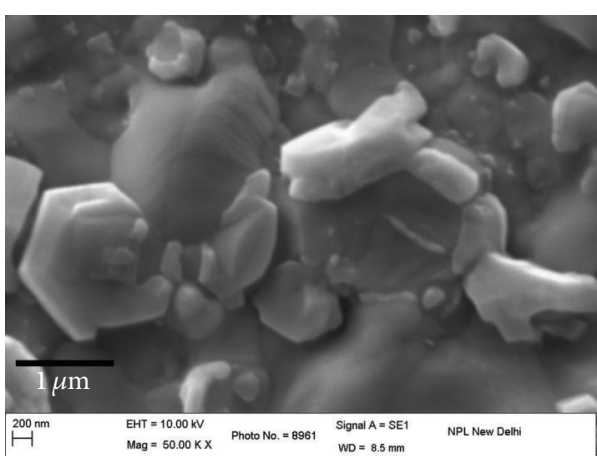

(a)

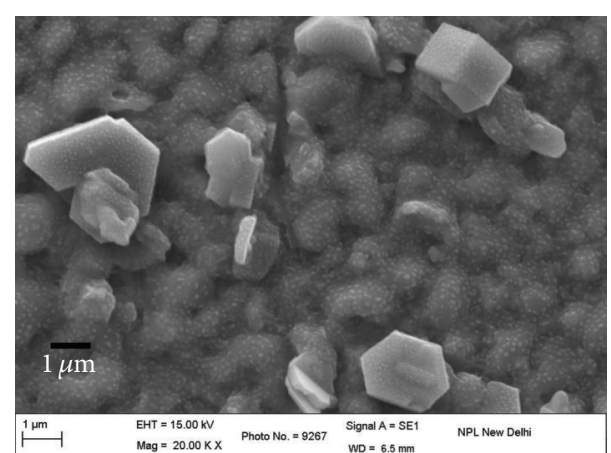

(b)

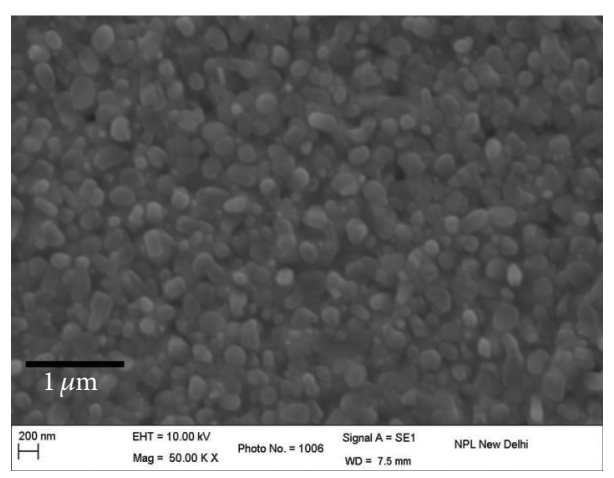

(c)

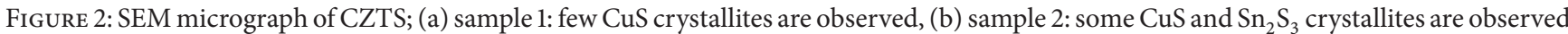
at the surface, and (c) sample S3: surface consists of columnar grains.

$50.4 \%$, respectively. This kind of columnar growth may be beneficial for decreasing the minority carrier recombination in CZTS solar cell device.

Sample 3 was further investigated using Raman spectroscopy, and the result is shown in Figure 3. The observed peaks at 332 and $285 \mathrm{~cm}^{-1}$ in the Raman study are consistent with the Raman peaks of CZTS kesterite structure [21, 22]. Thus, GIXRD and Raman studies confirmed the kesterite CZTS structure of the film.

The optical absorption coefficients of the CZTS thin films in the energy range $1.1 \mathrm{eV}-4.0 \mathrm{eV}$ were studied. The absorption coefficient was larger than $10^{4} \mathrm{~cm}^{-1}$ in the visible region, which is consistent with the reported literatures $[1$, 23-28]. The band gap for the direct band gap materials can be estimated using the following:

$$
(\alpha h v)^{2}=A\left(h v-E_{g}\right) .
$$

Based on the allowed direct interband transition, the band gap of film 3 was determined to be $1.50 \pm 0.01 \mathrm{eV}$ by extrapolating the linear $(\alpha h \nu)^{2}$ versus $h v$ plots to $(\alpha h \nu)^{2}=$ 0 , as shown in Figure 4. The value of band gap is in good agreement with the band gaps reported for CZTS films [1,2329]. This value is quite close to the theoretical optimal value reported for a single-junction solar cell.

The hot-probe measurement indicated that the CZTS thin film was p-type. The Hall effect measurement was carried out in a magnetic field intensity of $0.5 \mathrm{~T}$ and current

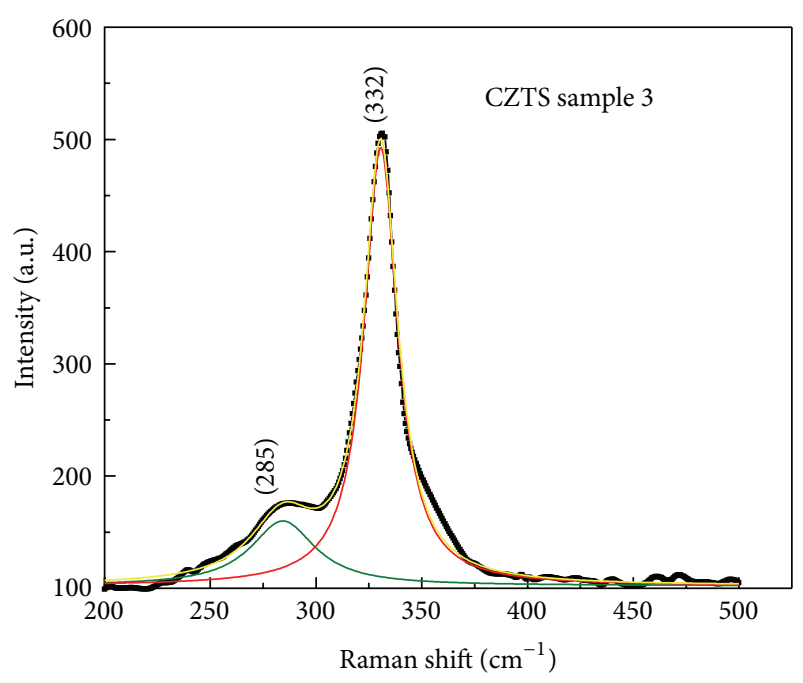

FIgure 3: Raman spectrum of CZTS sample 3. Peaks at 285 and 332 correspond to CZTS.

flow of $1.0 \mathrm{~mA}$. The values of the Hall coefficient, carrier concentration, resistivity, and mobility of the CZTS film 3 using the Van der Pauw geometry were $4.9 \times 10^{2} \mathrm{~cm}^{3} \mathrm{C}^{-1}$, $1.25 \times 10^{16} \mathrm{~cm}^{-3}, 7.6 \Omega \mathrm{cm}$, and $65 \mathrm{~cm}^{2} \mathrm{~V}^{-1} \mathrm{~s}^{-1}$, respectively. In one study, Zhou et al. have reported a value of $3.81 \times 10^{18} \mathrm{~cm}^{-3}$ for carrier concentration and $12.61 \mathrm{~cm}^{2} \mathrm{~V}^{-1} \mathrm{~s}^{-1}$ for the Hall 


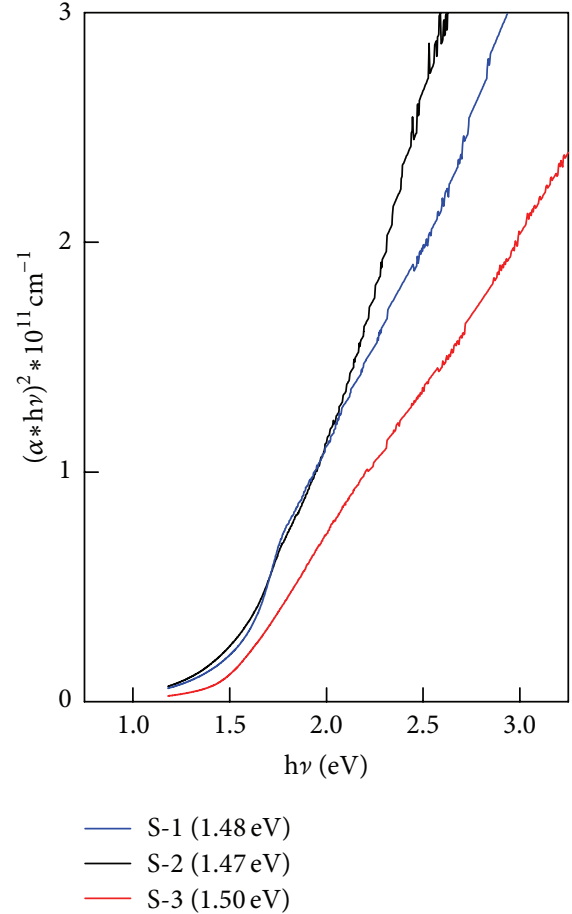

FIGURE 4: $(\alpha h \nu)^{2}$ versus photon energy $(h v)$ plot for CZTS films 1, 2, and 3.

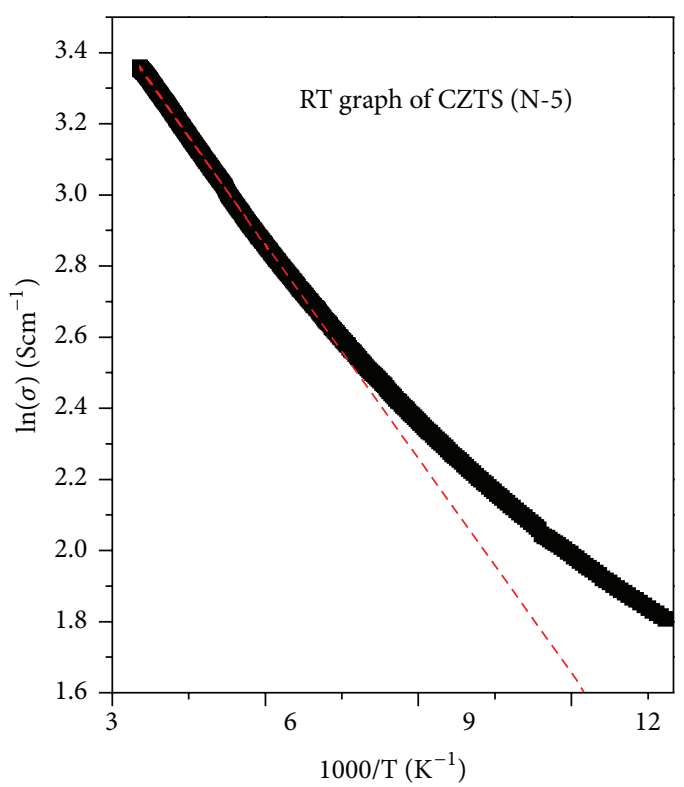

FIgURE 5: Temperature-dependent electrical conductivity for sample 3.

mobility in screen printed $\mathrm{Cu}_{2} \mathrm{ZnSnS}_{4}$ layers made on polyimide substrate. The screen printing paste was made from CZTS microparticles prepared by ball milling and sintering methods [30]. The positive value of the Hall coefficient confirmed the p-type nature of CZTS films. The obtained value of carrier concentration is similar to the values reported for device quality CIGS $[31,32]$ and also similar to the values

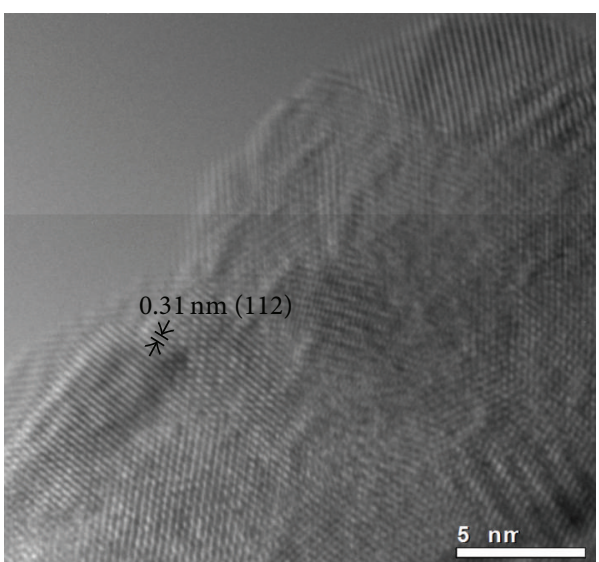

FIGURE 6: HRTEM micrographs of CZTS sample 3.

reported for CZTS by Liu et al. [1], Scragg et al. [29, 33], and Katagiri [34]. The resistivity value of thin film is similar to the results reported for CZTS film prepared by sulfurization of metallic precursors $[1,35]$ and spray pyrolysis method $[26,36]$. The conductivity of the film was also measured in the temperature range of 77-300 K. Activation energy was calculated using the slope of the $\ln (\sigma)$ versus $1000 / \mathrm{T}(\mathrm{K})$ graph (Figure 5). The calculated value of $E_{a} \sim 35 \mathrm{meV}$ is similar to the value of $E_{a} \sim 29-40 \mathrm{meV}$ reported by Leitao et al. [37] and Gonzalez et al. [38]. With CZTS being a ptype semiconductor, this value of activation energy indicates that the mobility of free holes is almost independent of the temperature; that is, the free holes have enough energy to flow over the grain potential barriers.

Figure 6 shows the HRTEM micrograph of CZTS thin film sample 3. The lattice spacing of $0.31 \mathrm{~nm}$ corresponds to the (112) plane of kesterite CZTS. The different orientation shows the polycrystalline nature of the sample.

In short, it is to be noted that this is the first study on cosputtering from the metal targets and sulfurization in ambient $\mathrm{H}_{2} \mathrm{~S}$. Using metal targets helps in controlling the composition of the film. It has been shown in the present study (with the help of GIXRD, SEM, and EDS) that various other sulfide phases are also formed depending upon the initial composition of metallic film. These sulfide phases may pose a problem in making the solar cell. The present study will provide a guideline for controlling the stoichiometry of CZTS films and avoiding the formation of secondary phases.

\section{Conclusions}

$\mathrm{Cu}_{2} \mathrm{ZnSnS}_{4}$ (CZTS) thin films were grown on soda-lime glass substrates by cosputtering from individual metal targets and sulfurization in ambient $\mathrm{H}_{2} \mathrm{~S}$ for the first time and were characterized by Raman, XRD, SEM, EDS, XRF, HRTEM, optical transmittance (UV-Vis), the Hall measurements, and RT measurements. Films having CZTS phase with good crystallinity and strong preferentially oriented growth along (112) plane have been deposited. The values of the Hall coefficient, carrier concentration, resistivity, and mobility of the CZTS film were $4.9 \times 10^{2} \mathrm{~cm}^{3} \mathrm{C}^{-1}, 1.25 \times 10^{16} \mathrm{~cm}^{-3}$, 
$7.6 \Omega \mathrm{cm}$, and $65 \mathrm{~cm}^{2} \mathrm{~V}^{-1} \mathrm{~s}^{-1}$, respectively. The grown CZTS film demonstrated an optical absorption coefficient higher than $10^{4} \mathrm{~cm}^{-1}$ and optical band gap of $1.50 \pm 0.01 \mathrm{eV}$. The optical and electrical properties showed that the thin film is suitable for solar cell applications.

\section{Acknowledgments}

Authors are grateful to Director, NPL, and Professor R. C. Budhani for his close guidance in this work. Dr. S. Kala's help in setting up the sulfurization system is acknowledged. The authors are thankful to CSIR-India and MNRE, Government of India (Sanction no. 31/29/2010-11/PVSE) for their financial support. N. Muhunthan and Om Pal Singh are thankful to UGC for the SRF and JRFship.

\section{References}

[1] F. Liu, Y. Li, K. Zhang, B. Wang, C. Yan et al., "In situ growth of $\mathrm{Cu}_{2} \mathrm{ZnSnS}_{4}$ thin films by reactive magnetron co-sputtering," Solar Energy Materials and Solar Cells, vol. 94, no. 12, pp. 24312434, 2010.

[2] P. Jackson, D. Hariskos, E. Lotter et al., "New world record efficiency for $\mathrm{Cu}(\mathrm{In}, \mathrm{Ga}) \mathrm{Se}_{2}$ thin-film solar cells beyond 20\%," Progress in Photovoltaics, vol. 19, no. 7, pp. 894-897, 2011.

[3] M. J. Romero, H. Du, G. Teeter, Y. Yan, and M. M. AlJassim, "Comparative study of the luminescence and intrinsic point defects in the kesterite $\mathrm{Cu} 2 \mathrm{Zn}_{2} \mathrm{SnS}_{4}$ and chalcopyrite $\mathrm{Cu}(\mathrm{In}, \mathrm{Ga}) \mathrm{Se}_{2}$ thin films used in photovoltaic applications," Physical Review B, vol. 84, no. 16, Article ID 165324, 5 pages, 2011.

[4] T. K. Todorov, J. Tang, S. Bag, O. Gunawan, T. Gokmen et al., "Beyond $11 \%$ efficiency: characteristics of state-of-the-art $\mathrm{cu}_{2} \mathrm{ZnSn}(\mathrm{S}, \mathrm{Se})_{4}$ solar cells," Advanced Energy Materials, vol. 3, no. 1, pp. 34-38, 2013.

[5] B. Shin, O. Gunawan, Y. Zhu, N. A. Bojarczuk, S. J. Chey et al., "Thin film solar cell with $8.4 \%$ power conversion efficiency using an earth-abundant $\mathrm{Cu}_{2} \mathrm{ZnSnS}_{4}$ absorber," Progress in Photovoltaics, vol. 21, no. 1, pp. 72-76, 2011.

[6] G. Zoppi, I. Forbes1, R. W. Miles1, P. J. Dalez, J. J. Scragg et al., " $\mathrm{Cu}_{2} \mathrm{ZnSnSe}_{4}$ thin film solar cells produced by selenisation of magnetron sputtered precursors," Progress in Photovoltaics, vol. 17, no. 5, pp. 315-319, 2009.

[7] H. Katagiri, K. Jimbo, S. Yamada, T. Kamimura, W. S. Maw et al., "Enhanced conversion efficiencies of $\mathrm{Cu}_{2} \mathrm{ZnSnS}_{4}$-based thin film solar cells by using preferential etching technique," Applied Physics Express, vol. 4, Article ID 041201, 2008.

[8] L. Sun, J. He, H. Kong, F. Yue, P. Yang et al., "Structure, composition and optical properties of $\mathrm{Cu}_{2} \mathrm{ZnSnS}_{4}$ thin films deposited by pulsed Laser deposition method," Solar Energy Materials and Solar Cells, vol. 95, no. 10, pp. 2907-2913, 2011.

[9] K. Maeda, K. Tanaka, Y. Fukui, and H. Uchiki, "Influence of $\mathrm{H} 2 \mathrm{~S}$ concentration on the properties of $\mathrm{Cu}_{2} \mathrm{ZnSnS}_{4}$ thin films and solar cells prepared by solgel sulfurization," Solar Energy Materials and Solar Cells, vol. 95, no. 10, pp. 2855-2860, 2011.

[10] B. S. Pawar, S. M. Pawar, K. V. Gurav, S. W. Shin, J. Y. Lee et al., "Effect of annealing atmosphere on the properties of electrochemically deposited $\mathrm{Cu}_{2} \mathrm{ZnSnS}_{4}$ (CZTS) thin films," ISRN Renewable Energy, vol. 2011, Article ID 934575, 5 pages, 2011.
[11] Q. Guo, G. M. Ford, W.-C. Yang et al., "Fabrication of 7.2\% efficient CZTSSe solar cells using CZTS nanocrystals," Journal of the American Chemical Society, vol. 132, no. 49, pp. 1738417386, 2010.

[12] F. Liu, K. Zhang, Y. Lai, J. Li, Z. Zhang, and Y. Liu, "Growth and characterization of $\mathrm{Cu}_{2} \mathrm{ZnSnS}_{4}$ thin films by dc reactive magnetron sputtering for photovoltaic applications," Electrochemical and Solid-State Letters, vol. 13, no. 11, pp. H379-H381, 2010.

[13] H. Yoo and J. Kim, "Growth of $\mathrm{Cu}_{2} \mathrm{ZnSnS}_{4}$ thin films using sulfurization of stacked metallic films," Thin Solid Films, vol. 518, no. 22, pp. 6567-6572, 2010.

[14] J. S. Seol, S. Y. Lee, J. C. Lee, H. D. Nam, and K. H. Kim, "Electrical and optical properties of $\mathrm{Cu}_{2} \mathrm{ZnSnS}_{4}$ thin films prepared by rf magnetron sputtering process," Solar Energy Materials and Solar Cells, vol. 75, no. 1-2, pp. 155-162, 2003.

[15] C. Platzer-Björkman, J. Scragg, H. Flammersberger, T. Kubart, and M. Edoff, "Influence of precursor sulfur content on film formation and compositional changes in $\mathrm{Cu}_{2} \mathrm{ZnSnS}_{4}$ films and solar cells," Solar Energy Materials and Solar Cells, vol. 98, pp. 110-117, 2012.

[16] J. B. Li, V. Chawla, and B. M. Clemens, "Investigating the role of grain boundaries in CZTS and CZTSSe thin film solar cells with scanning probe microscopy," Advanced Materials, vol. 24, no. 6, pp. 720-723, 2012.

[17] W. M. Hlaing OO, J. L. Johnson, A. Bhatia, E. A. Lund, M. M. Nowell, and M. A. Scarpulla, "Grain size and texture of $\mathrm{Cu}_{2} \mathrm{ZnSnS}_{4}$ thin films synthesized by cosputtering binary sulfides and annealing: effects of processing conditions and sodium," Journal of Electronic Materials, vol. 40, no. 11, pp. 22142221, 2011.

[18] A. Khalkar, K. S. Lim, S. M. Yu, S. P. Patole, and J. B. Yoo, "Effect of growth parameters and annealing atmosphere on the properties of $\mathrm{Cu}_{2} \mathrm{ZnSnS}_{4}$ thin films deposited by cosputtering," International Journal of Photoenergy, vol. 2013, Article ID 690165, 7 pages, 2013.

[19] G. Gurieva, M. Guc, L. I. Bruk et al., " $\mathrm{Cu}_{2} \mathrm{ZnSnS}_{4}$ thin films grown by spray pyrolysis: characterization by Raman spectroscopy and X-ray diffraction," physica Status Solidi (c), vol. 2013, 2013.

[20] H. Katagiri, K. Saitoh, T. Washio, H. Shinohara, T. Kurumadani, and S. Miyajima, "Development of thin film solar cell based on $\mathrm{Cu}_{2} \mathrm{ZnSnS}_{4}$ thin films," Solar Energy Materials and Solar Cells, vol. 65, no. 1, pp. 141-148, 2001.

[21] Z. Su, C. Yan, K. Sun, Z. Han, F. Liu et al., "Preparation of $\mathrm{Cu}_{2} \mathrm{ZnSnS}_{4}$ thin films by sulfurizing stacked precursor thin films via successive ionic layer adsorption and reaction method," Applied Surface Science, vol. 258, no. 19, pp. 7678-7682, 2012.

[22] W. Li, K. Jiang, J. Zhang, X. Chen, Z. Hu, S. Chen et al., “Temperature dependence of phonon modes, dielectric functions, and interband electronic transitions in $\mathrm{Cu}_{2} \mathrm{ZnSnS}_{4}$ semiconductor films," Physical Chemistry Chemical Physics, vol. 14, no. 28, pp. 9936-9941, 2012.

[23] K. Ito and T. Nakazawa, "Electrical and optical properties of stannite-type quaternary semiconductor thin films," Japanese Journal of Applied Physics, vol. 27, pp. 2094-2097, 1988.

[24] T. Tanaka, T. Nagatomo, D. Kawasaki et al., "Preparation of $\mathrm{Cu}_{2} \mathrm{ZnSnS}_{4}$ thin films by hybrid sputtering," Journal of Physics and Chemistry of Solids, vol. 66, no. 11, pp. 1978-1981, 2005. 
[25] K. Tanaka, N. Moritake, and H. Uchiki, "Preparation of $\mathrm{Cu}_{2} \mathrm{ZnSnS}_{4}$ thin films by sulfurizing sol-gel deposited precursors," Solar Energy Materials and Solar Cells, vol. 91, no. 13, pp. 1199-1201, 2007.

[26] Y. B. K. Kumar, G. S. Babu, P. U. Bhaskar, and V. S. Raja, "Preparation and characterization of spray-deposited $\mathrm{Cu}_{2} \mathrm{ZnSnS}_{4}$ thin films," Solar Energy Materials and Solar Cells, vol. 93, no. 8, pp. 1230-1237, 2009.

[27] C. P. Chan, H. Lam, and C. Surya, "Preparation of $\mathrm{Cu}_{2} \mathrm{ZnSnS}_{4}$ films by electrodeposition using ionic liquids," Solar Energy Materials and Solar Cells, vol. 94, no. 2, pp. 207-211, 2010.

[28] K. Tanaka, M. Oonuki, N. Moritake, and H. Uchiki, " $\mathrm{Cu}_{2} \mathrm{ZnSnS}_{4}$ thin film solar cells prepared by non-vacuum processing," Solar Energy Materials and Solar Cells, vol. 93, no. 5, pp. 583-587, 2009.

[29] J. J. Scragg, P. J. Dale, and L. M. Peter, "Synthesis and characterization of $\mathrm{Cu}_{2} \mathrm{ZnSnS}_{4}$ absorber layers by an electrodepositionannealing route," Thin Solid Films, vol. 517, no. 7, pp. 2481-2484, 2009.

[30] Z. Zhou, Y. Wang, D. Xu, and Y. Zhang, "Fabrication of $\mathrm{Cu}_{2} \mathrm{ZnSnS}_{4}$ screen printed layers for solar cells," Solar Energy Materials and Solar Cells, vol. 94, no. 12, pp. 2042-2045, 2010.

[31] D. Lincot, H. Gomez Meier, J. Kessler, J. Vedel, B. Dimmler, and H. W. Schock, "Photoelectrochemical study of p-type copper indium diselenide thin films for photovoltaic applications," Solar Energy Materials, vol. 20, no. 1-2, pp. 67-79, 1990.

[32] C. Guillen, J. Herrero, and D. Lincot, "Photovoltaic activity of electrodeposited $p$-CuInSe $e_{2}$ /electrolyte junction," Journal of Applied Physics, vol. 76, no. 1, pp. 359-362, 1994.

[33] J. J. Scragg, P. J. Dale, and L. M. Peter, “Towards sustainable materials for solar energy conversion: preparation and photoelectrochemical characterization of $\mathrm{Cu}_{2} \mathrm{ZnSnS}_{4}$," Electrochemistry Communicationsn, vol. 10, no. 4, pp. 639-642, 2008.

[34] H. Katagiri, " $\mathrm{Cu}_{2} \mathrm{ZnSnS}_{4}$ thin film solar cells," Thin Solid Films, vol. 480-481, pp. 426-432, 2005.

[35] H. Katagiri, N. Sasaguchi, S. Hando, S. Hoshino, J. Ohashi, and T. Yokota, "Preparation and evaluation of $\mathrm{Cu}_{2} \mathrm{ZnSnS}_{4}$ thin films by sulfurization of E-B evaporated precursors," Solar Energy Materials and Solar Cells, vol. 49, no. 1-4, pp. 407-414, 1997.

[36] N. Nakayama and K. Ito, "Sprayed films of stannite $\mathrm{Cu}_{2} \mathrm{ZnSnS}_{4}$," Applied Surface Science, vol. 92, pp. 171-175, 1996.

[37] J. P. Leitao, N. M. Santos, P. A. Fernandes, P. M. P. Salome, A. F. da Cunha et al., "Photoluminescence and electrical study of fluctuating potentials in $\mathrm{Cu}_{2} \mathrm{ZnSnS}_{4}$-based thin films," Physical Review B, vol. 84, no. 2, Article ID 024120, 2011.

[38] J. C. Gonzalez, G. M. Ribeiro, E. R. Viana, P. A. Fernandes, P. M. P. Salome et al., "Hopping conduction and persistent photoconductivity in $\mathrm{Cu}_{2} \mathrm{ZnSnS}_{4}$ thin films," Journal of Physics D, vol. 46, no. 15, Article ID 155107, 2013. 

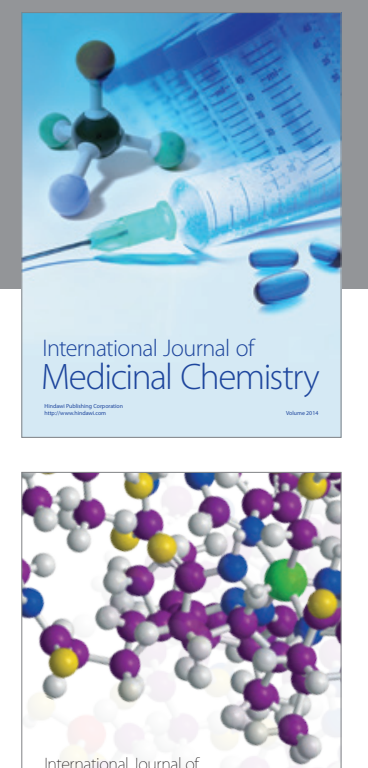

\section{Carbohydrate} Chemistry

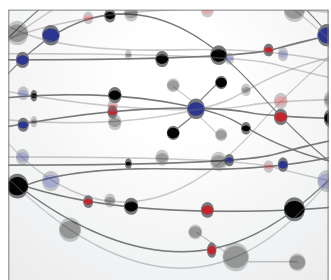

The Scientific World Journal
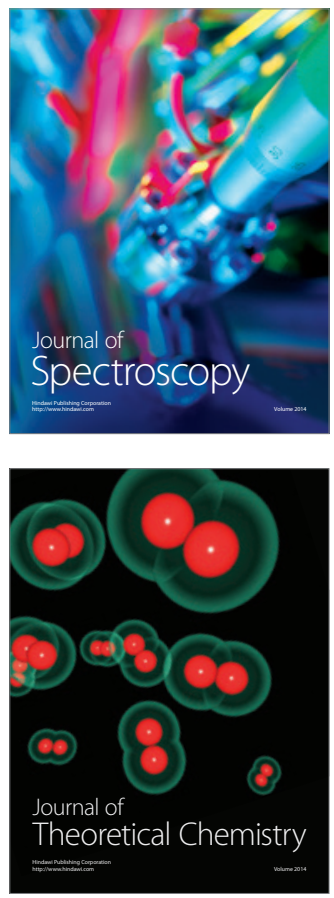
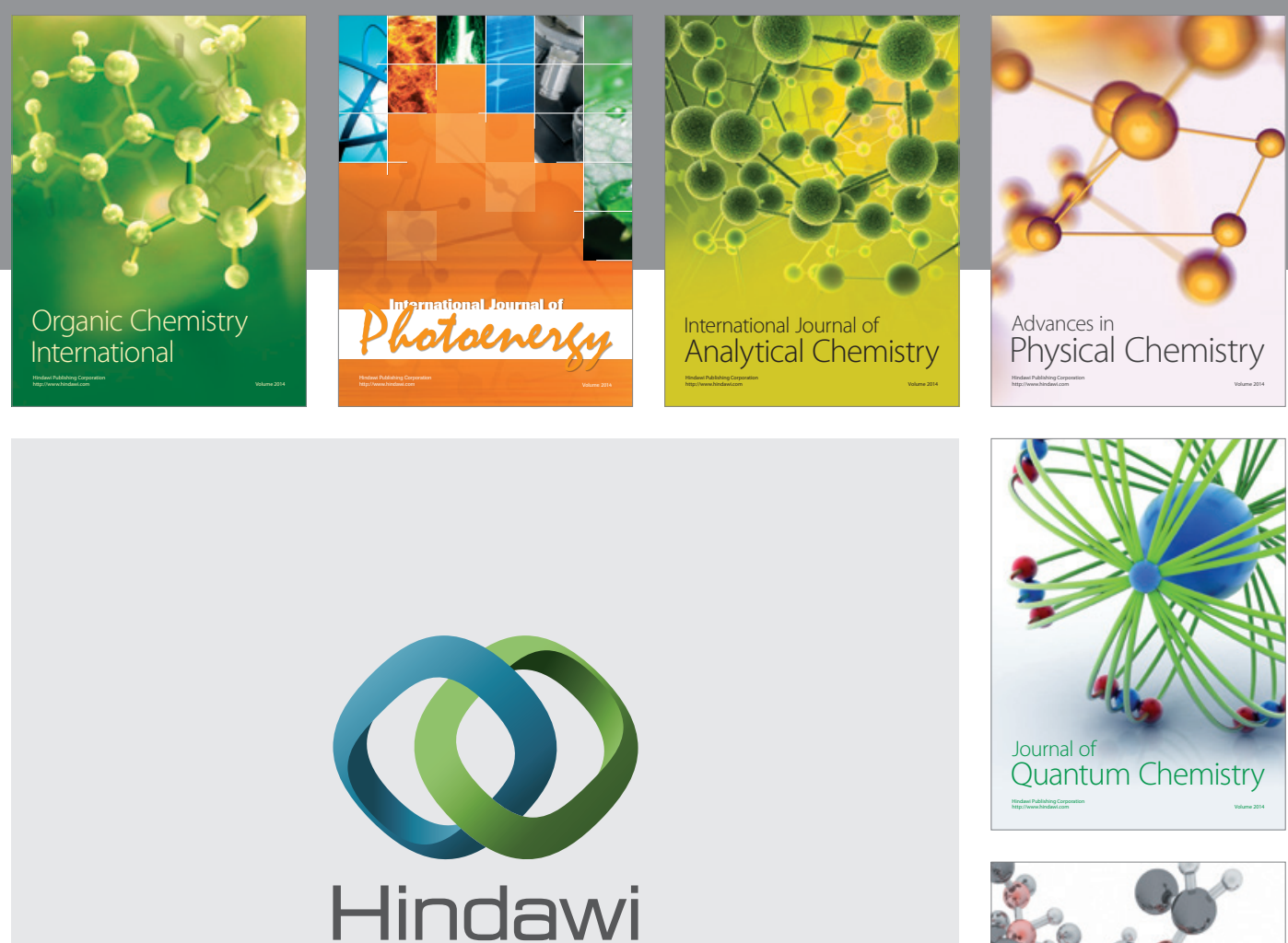

Submit your manuscripts at

http://www.hindawi.com

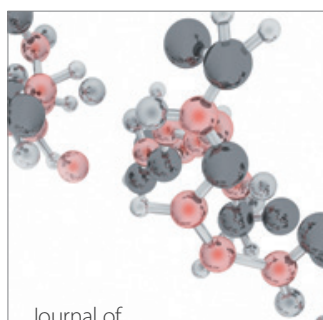

Analytical Methods

in Chemistry

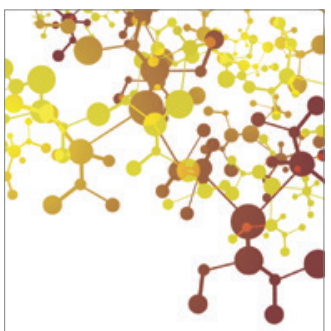

Journal of

Applied Chemistry

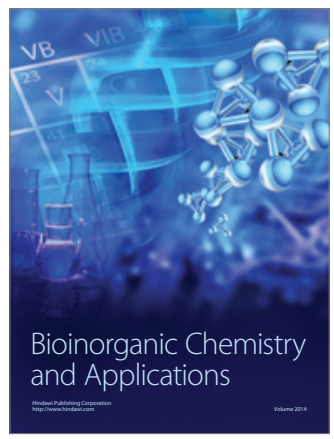

Inorganic Chemistry
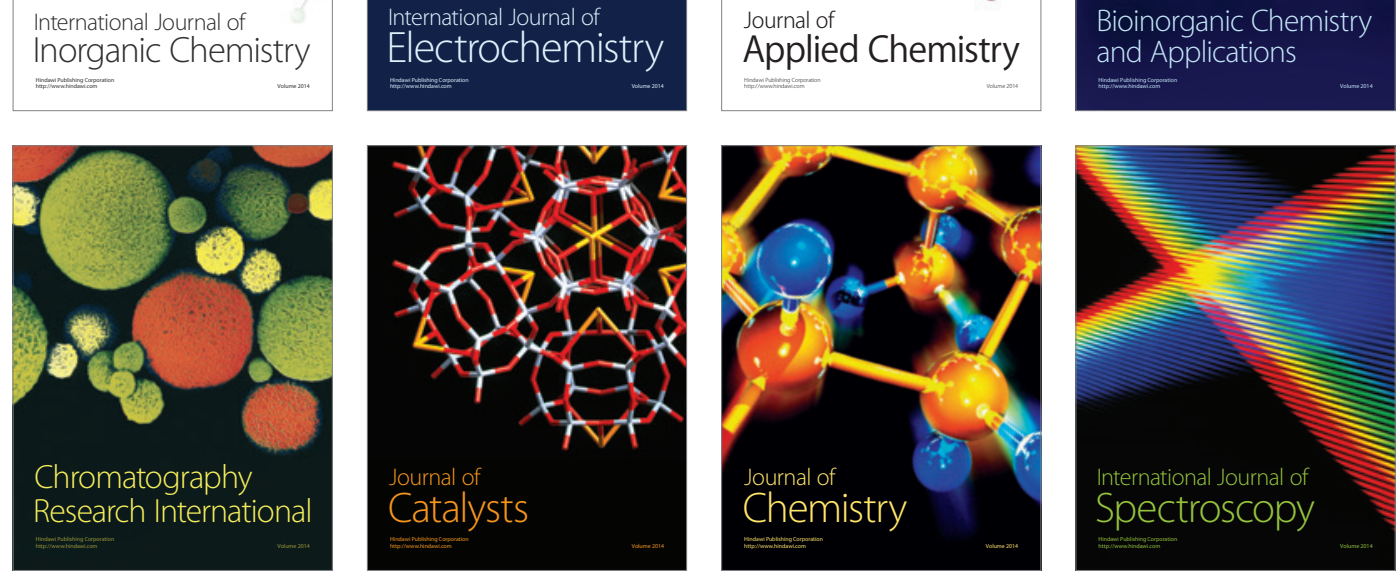